\title{
Crop coefficients of $B t$. cotton under variable moisture regimes and mulching
}

\author{
G. V. PRAJAPATI ${ }^{1}$ and R. SUBBAIAH ${ }^{2}$ \\ ${ }^{1}$ Centre of Excellence on Soil \& Water Management, Junagadh Agricultural University, Junagadh-362 001 \\ ${ }^{2}$ College of Agricultural Engineering and Technology, Anand Agricultural University, Godhra \\ Email:prajapti_girish@jau.in; ranga3711@gmail.com
}

\begin{abstract}
An experiment was undertaken for two years (2013-14 and 2014-15) on sandy loam soils of Junagadh $\left(21^{\circ} 30^{\prime} \mathrm{N}, 70^{\circ} 27^{\prime} \mathrm{E}\right)$ to determine crop coefficients of Bt. cotton under three mulch treatments $\left(M_{1}\right.$ - silver black plastic mulch, $M_{2}$ - biodegradable plastic mulch, $M_{3}-$ wheat straw mulch and $C$ - control) with two irrigation regimes $\left(\mathrm{I}_{1}-1.0 \mathrm{IW} / \mathrm{ET}_{\mathrm{c}}, \mathrm{I}_{2}-0.8 \mathrm{IW} / \mathrm{ET}_{\mathrm{c}}\right)$. Actual evapotranspiration was estimated using soil moisture sensors. Results revealed that adjusted $\mathrm{FAO} \mathrm{K}_{\mathrm{c}}$ predicts higher value than sensor based $\mathrm{K}_{\mathrm{c}}$ values at both irrigation regimes. Silver black plastic mulch recorded lower crop coefficient values at all growth stage of Bt. cotton compared to biodegradable plastic mulch, wheat straw mulch and control. Sensor based $\mathrm{K}_{\mathrm{c} \text { ini }}$ and $\mathrm{K}_{\mathrm{c} \text {-dev }}$ values of silver black plastic mulch observed 72.2, 29.0 and 66.9 and 14.8 per cent lower than control at $1.0 \mathrm{IW} / \mathrm{ET}_{\mathrm{c}}$ and $0.8 \mathrm{IW} / \mathrm{ET}_{\mathrm{c}}$ respectively. Overestimated adjusted $\mathrm{FAO} \mathrm{K}_{\mathrm{c}}$ values caused a loss of $78.1 \mathrm{~mm}$ and $66.5 \mathrm{~mm}$ of precious water at $1.0 \mathrm{IW} / \mathrm{ET}_{\mathrm{c}}$ and $0.8 \mathrm{IW} / \mathrm{ET}_{\mathrm{c}}$ respectively. This study admonishes blind adoption of published FAO $\mathrm{K}_{\mathrm{c}}$ curves for mulch conditions.
\end{abstract}

Keywords : Silver black plastic mulch, Biodegradable mulch, Crop coefficient, Drip irrigation andIrrigation regimes

Indian economy continues to receive great support from the most important commercial fibre crop. Paucity of quantity and quality of groundwater reserves, high evaporative and deficient rainfall condition, enhanced pest and insect damage due to climate change are some of the detrimental factors for poor cotton yields in Gujarat state. Combined influence of carbon and water cycle is adding another dimension to the improved productivity. To combat the abiotic and biotic stress on the crop, farmers of this region are adopting drip irrigation with organic and inorganic mulches in Bt. cotton on mass scale (Mariani and Ferrante, 2017). Major constraints for reducing the water productivity are lack of knowledge on irrigation scheduling for mulched cotton and poor design of the drip system (Hajare et al., 2008 and Rajendra et al., 2012).Determination of crop evapotranspiration $\left(\mathrm{ET}_{\mathrm{c}}\right.$ ) is the most fundamental requirement for proper scheduling of irrigation Jaspinder Kaur et al., 2017). Experimentally, determination of crop coefficient $\left(\mathrm{K}_{\mathrm{c}}\right)$ is multiplied by reference crop evapotranspiration $\left(\mathrm{ET}_{\mathrm{o}}\right)$ to compute $\mathrm{ET}_{\mathrm{c}}$ (Chowdhary and Shrivastava, 2010).

The FAO-56 promotes Penman-Monteith (P-M) combination equation which requires data of temperature, relative humidity, wind speed, and solar radiation. This data demand is the main constraint on its use in locations where climate data are limited (Rahimikhoob, et al., 2012). Tables of $\mathrm{K}_{\mathrm{c}}$ values derived from field and lysimeter $\mathrm{ET}_{\mathrm{c}}$ measurements are provided in literature. The practical simplicity of using the $\mathrm{K}_{\mathrm{c}}$ approach is indisputable, but the adoption of generalized $\mathrm{K}_{\mathrm{c}}$ curves can lead to errors. Since local development of $\mathrm{K}_{\mathrm{c}}$ is a difficult task, most practitioners rely on the published values. No study is reported to develop crop coefficient for drip irrigated silver black plastic mulch, biodegradable plastic mulch and wheat straw mulch cotton subjected to variable irrigation regimes in this region. Therefore, the study was undertaken to develop the $\mathrm{K}_{c}$ curves for drip irrigated mulched cotton using soil moisture sensors installed at different depths.

\section{MATERIALS AND METHODS}

The field experiment was conducted at Junagadh Agricultural University $\left(21^{\circ} 30^{\prime} \mathrm{N}, 70^{\circ} 27^{\prime} \mathrm{E}\right.$ and 77.5 above mean sea level) for two consecutive years during Kharif season of 2013-14 and 2014-15.The experiment was laid out in split plot design with main plot treatments of mulches (i.e. Silver black plastic mulch $\left(\mathrm{M}_{1}\right)$, biodegradable plastic mulch (20 micron) $\left(M_{2}\right)$ and wheat straw mulched $\left(M_{3}\right)$ cotton (Hy-6, BG-II) and sub-treatments of irrigation regimes;(i.e. $1.0 \mathrm{IW} / \mathrm{ETc}\left(\mathrm{I}_{1}\right)$ and $0.8 \mathrm{IW} / \mathrm{ET}_{\mathrm{c}}\left(\mathrm{I}_{2}\right)$ along with no mulch $(\mathrm{C})$. Soil is sandy loam (1-1.5m depth) with volumetric water content at field capacity and permanent wilting point determined at 39 and 15 per cent, respectively. Two cotton seeds were sown at $2.5 \mathrm{~cm}$ depth directly through the holes 
made on the mulch film. Thinning as well as gap filling was done after germination of plants. The recommended package of agronomical practices was adopted. Recommended dose of fertilizer (160:0:120 NPK, $\mathrm{kg} \mathrm{ha}^{-1}$ ) was applied. Fifty per cent $\mathrm{N}$ and $\mathrm{K}$ fertilizers was given as basal before spreading the mulching sheet. The remaining $\mathrm{N}$ and $\mathrm{K}$ was given as four equal splits at different phonological stages (i.e. vegetative, bud formation, flowering and boll development) was applied through drip irrigation. Irrigation water were applied by using heavy duty black colored LLDPE lateral line of $1.6 \mathrm{~cm}$ diameter@ $2.5 \mathrm{kgcm}^{-2}$ with emitter/dripper discharge rate of 2 lph alongwith dripper spacing of $40 \mathrm{~cm}$.

\section{Determination of FAO $K_{c}$ curves}

Crop coefficient $\left(\mathrm{K}_{\mathrm{c}}\right)$ is determined for $\mathrm{a}$ ) as per the FAO-56 approach b) for a particular mulch as suggested by FAO-56 and c) for a particular mulch and for a particular irrigation interval as per the sensor based daily observations.

\section{a) $\quad K_{c}$ for no mulch as per FAO-56}

Crop coefficient for the initial stage $\left(\mathrm{K}_{\text {c-ini }}\right)$ calculated using procedure suggested by FAO for a trickle irrigation system from the following figure given by FAO-56 (Allen $e t$ al. 1998).

$K_{\text {cini }}=f_{w} \times K_{\text {cini }(\text { Tab Fig })}$

Irrigation depth of water for the part of the surface wetted calculated as:

$I_{w}=\frac{I}{f_{w}}$

The crop coefficient of cotton crop as per FAO is 0.35 (using equation 1), 1.15-1.20 and 0.70-0.50 for $\mathrm{K}_{\mathrm{c}-\text { ini, }}, \mathrm{K}_{\mathrm{c} \text {-mid }}$ and $\mathrm{K}_{\mathrm{c}-}$ end, respectively from Table 12 of FAO 56 for drip irrigated cotton crop without mulch (control), The above values were corrected for non-standard conditions using FAO-56 procedure.

$$
\begin{aligned}
& K_{C \text { mid }}=K_{C \text { mid (Tab) }}+\left[0.04\left(u_{2}-2\right)-0.004\left(R H_{\min }-45\right]\left(\frac{h}{3}\right)^{0.3}\right. \\
& K_{C \text { end }}=K_{C \text { and }(T a b)}+\left[0.04\left(u_{2}-2\right)-0.004\left(R H_{\text {min }}-45\right]\left(\frac{h}{3}\right)^{0.3}\right.
\end{aligned}
$$

\section{b) $\quad K_{c}$ for mulched cotton as per FAO-56}

$\mathrm{K}_{\mathrm{c}}$ values decrease by an average of 10-30 per cent due to the 50-80 per cent reduction in soil evaporation. The value for $\mathrm{K}_{\text {c-ini }}$ under mulch is often as low as 0.10 suggested by FAO 56. So the crop coefficient of cotton crop under mulching were reduced by 15 per cent for $\mathrm{K}_{\mathrm{c} \text {-mid }}$ and $\mathrm{K}_{\mathrm{c} \text {-end }}$. Corrections for local conditions were followed as per equation 3 and 4 .

Reduce the amount of soil water evaporation by about 5 per cent for each 15 per cent of soil surface that is effectively covered by organic mulch as suggested by FAO56. So, the crop coefficients of cotton crop under mulching were reduced by 10 per cent for $\mathrm{K}_{\mathrm{c} \text {-mid }}$ and $\mathrm{K}_{\mathrm{c} \text {-end }}$. Corrections for local conditions as per given equation 3 and 4 .

\section{c) Crop coefficient based on moisture sensor observations}

Actual evapotranspiration $\mathrm{ET}_{\mathrm{a}}\left(\mathrm{ET}_{\mathrm{c}}\right)$ was calculated using soil moisture sensors with data loggers installed at different depth in different treatment for getting soil moisture periodically. It was calculated using following equation

$E T_{a}=1000 \times\left(M_{1}-M_{2}\right) \times Z_{r} \times B D$

Where, $E T_{a}=$ Actual Evapotranspiration (mm), $\mathrm{M}_{1}=$ Moisture content after irrigation $\left(\mathrm{m}^{3} \mathrm{~m}^{-3}\right), \mathrm{M}_{2}=$ Moisture content before irrigation $\left(\mathrm{m}^{3} \mathrm{~m}^{-3}\right), \mathrm{Zr}=$ Rooting depth $(\mathrm{m})$, $\mathrm{BD}=$ Bulk density $(\mathrm{g} / \mathrm{cc})$.

The reference crop evapotranspiration $\left(\mathrm{ET}_{0}\right)$ was estimated using Penman Monteith (PM FAO-56) equation

$E T_{0}=\frac{0.408 \Delta\left(R_{n}-G\right)+\gamma \frac{900}{T+273} u_{2}\left(e_{s}-e_{a}\right)}{\Delta+\gamma\left(1+0.34 u_{2}\right)}$

Where, $\mathrm{ET}_{0}$ is reference evapotranspiration ( $\mathrm{mm}^{-}$day $\left.{ }^{1}\right), R n$ is net radiation at the crop surface $\left(\mathrm{MJ} \mathrm{m}^{-2} \mathrm{day}^{-1}\right), G$ is soil heat flux density ( $\mathrm{MJ} \mathrm{m^{-2 }}$ day $\left.^{-1}\right), T$ is mean daily air temperature at $2 \mathrm{~m}$ height $\left({ }^{\circ} \mathrm{C}\right), u_{2}$ is wind speed at $2 \mathrm{~m}$ height $\left(\mathrm{m} \mathrm{s}^{-1}\right)$, es is saturation vapour pressure $(\mathrm{kPa}), e a$ is actual vapour pressure $(\mathrm{kPa}),(e s-e a)$ is saturation vapour pressure deficit $(\mathrm{kPa}), \Delta$ is slope vapour pressure curve $\left(\mathrm{kPa}^{\circ} \mathrm{C}^{-1}\right)$, and $\Upsilon$ is Psychrometric constant $\left(\mathrm{kPa}^{\circ} \mathrm{C}^{-1}\right)$.

The sensor based $\mathrm{K}_{\mathrm{c}}$ values were developed as

$K_{c}=E T_{a} / E T_{o}$

Sensor based $\mathrm{K}_{\mathrm{c}}$ curve was compared with $\mathrm{K}_{\mathrm{c}}$ curves developed as per FAO 56 for no mulch and with mulch conditions for different irrigation regimes $\left(1.0 \mathrm{IW} / \mathrm{ET}_{\mathrm{c}}\right.$ and $0.8 \mathrm{IW} / \mathrm{ET}_{\mathrm{c}}$ ).

Irrigation was given based on the equation (5) considering the application efficiency of drip irrigation 90 per cent at $1.0 \mathrm{IW} / \mathrm{ET}_{\mathrm{c}}$ and $0.8 \mathrm{IW} / \mathrm{ET}_{\mathrm{c}}$ 
Table 2: Irrigation water requirement estimated by different approaches

\begin{tabular}{|c|c|c|}
\hline \multirow[t]{2}{*}{ Treatments } & \multicolumn{2}{|c|}{ Irrigation water (mm) } \\
\hline & Sensor based ET & $\operatorname{Pan} \mathrm{ET}_{\mathrm{c}}$ \\
\hline \multicolumn{3}{|l|}{$\mathrm{M}_{1}$} \\
\hline $\mathrm{I}_{1}$ & 270.9 & 335.6 \\
\hline $\mathrm{I}_{2}$ & 227.6 & 268.5 \\
\hline \multicolumn{3}{|l|}{$\mathrm{M}_{2}$} \\
\hline $\mathrm{I}_{1}$ & 280.3 & 334.0 \\
\hline $\mathrm{I}_{2}$ & 231.7 & 267.2 \\
\hline \multicolumn{3}{|l|}{$\mathrm{M}_{3}$} \\
\hline $\mathrm{I}_{1}$ & 292.2 & 357.2 \\
\hline $\mathrm{I}_{2}$ & 238.6 & 285.8 \\
\hline \multicolumn{3}{|l|}{$\mathrm{C}$} \\
\hline $\mathrm{I}_{1}$ & 320.4 & 412.1 \\
\hline $\mathrm{I}_{2}$ & 257.1 & 329.7 \\
\hline \multicolumn{3}{|l|}{$\mathrm{CD}(0.05)$} \\
\hline M & 13.8 & 10.4 \\
\hline I & 28.1 & 55.7 \\
\hline MxI & 12.9 & 27.9 \\
\hline
\end{tabular}

\section{RESULTS AND DISCUSSION}

The study area is having typically subtropical and semi-arid climate, characterized by fairly cold and dry winter, hot and dry summer and warm and moderately humid during monsoon. Partial failure of monsoon once in three to four years is common in this region. The last 35 years weather data recorded at the Junagadh Agricultural University observatory located near to the experimental site showed that the variation in the weekly mean of daily maximum temperature, minimum temperature, relative humidity, wind speed, bright sun shine hours and pan evaporation were from 29.5 to $39.4{ }^{\circ} \mathrm{C}, 10$ to $26.7^{\circ} \mathrm{C}, 51$ to 88 per cent, 2.1 to $10.1 \mathrm{kmhr}^{-1}, 4.2$ to 13.4 hours and 3.6 to $10.7 \mathrm{~mm}$, respectively. The average annual rainfall and evaporation is $852.4 \mathrm{~mm}$ and $2482 \mathrm{~mm}$, respectively. During the period of experiments (June to January), the minimum and maximum pan evaporation, temperature and relative humidity were observed as $0.0 \mathrm{~mm}$ and $10.90 \mathrm{~mm}, 7.4^{\circ} \mathrm{C}$ and $39.50^{\circ} \mathrm{C}$ and 17.50 per cent and 99.0 per cent, respectively. The weather parameters were more or less congenial for favourable growth of cotton under irrigated condition during both years.

Determination of $K_{c}$ curves

$K_{c}$ for no mulch $: \mathrm{K}_{c \text { ini }}$ for drip irrigated cotton without mulch 


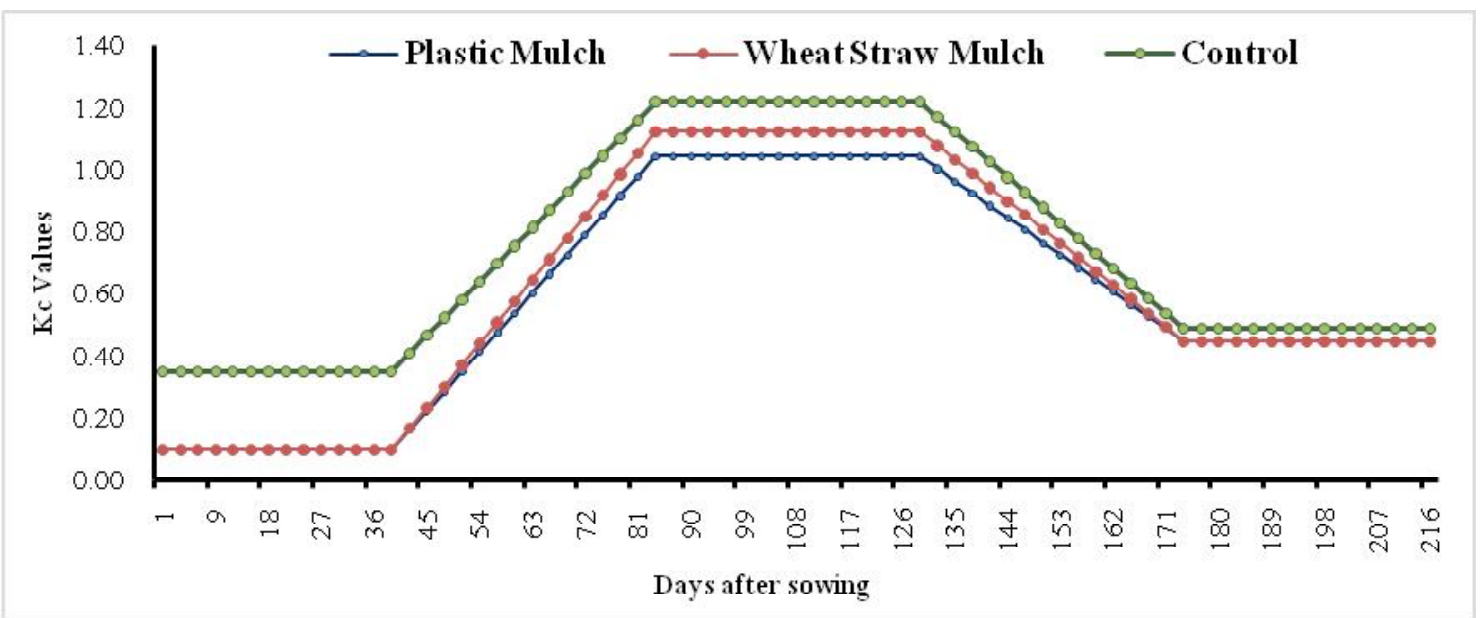

Fig. 1:Adjusted FAO Crop coefficient curves for mulch and no mulch conditions

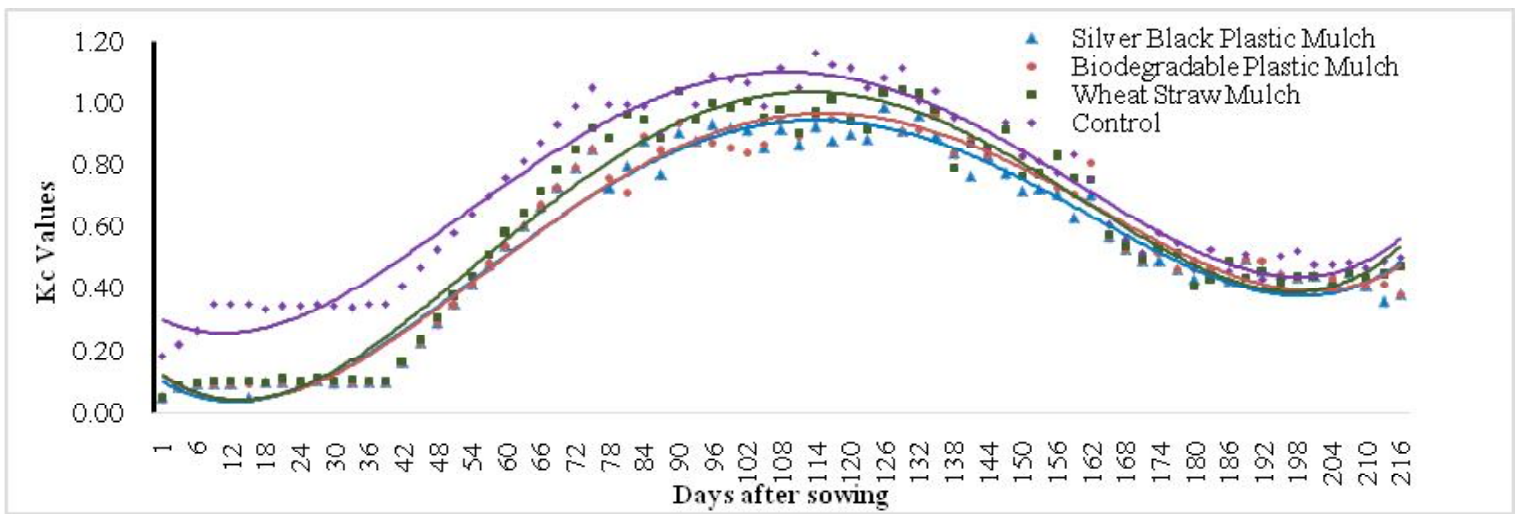

Fig. 2:Pooled sensor based $\mathrm{K}_{\mathrm{c}}$ curves for different treatment at $1.0 \mathrm{IW} / \mathrm{ET}_{\mathrm{c}}$

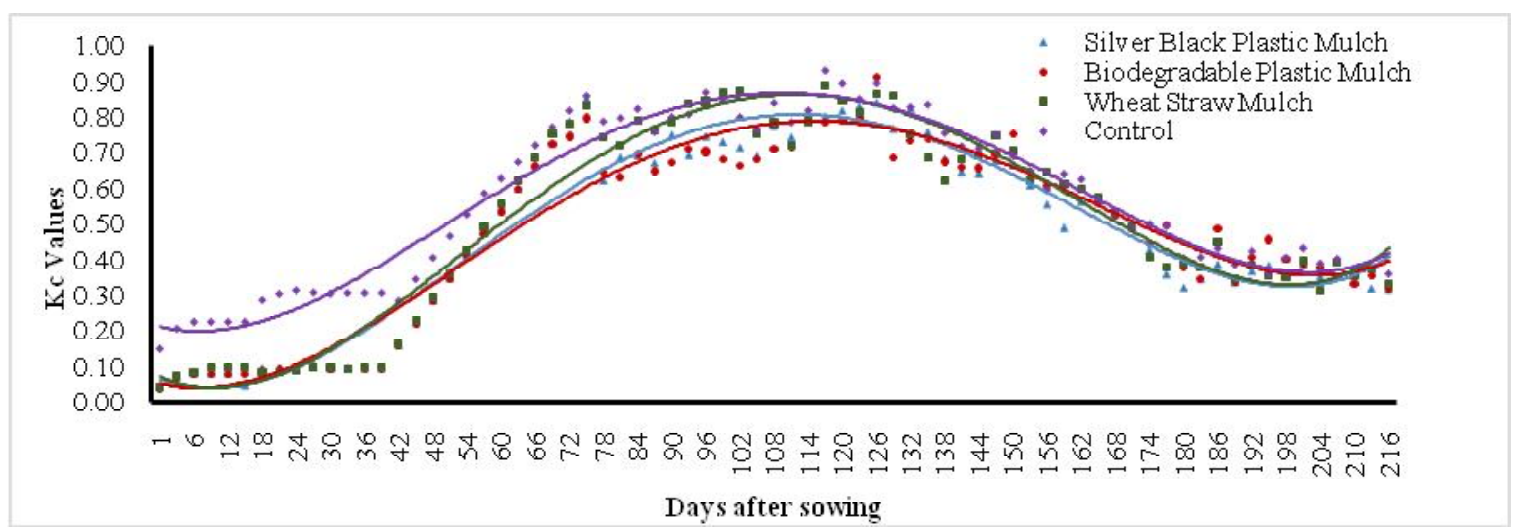

Fig. 3:Pooled sensor based $\mathrm{K}_{\mathrm{c}}$ curves for different treatment at $0.8 \mathrm{IW} / \mathrm{ET}_{\mathrm{c}}$

for 2013-14 and 2014-15 was 0.35 as per equation 1. FAO 56 suggested $\mathrm{K}_{\mathrm{c} \text { mid }}$ and $\mathrm{K}_{\text {cend }}$ values for drip irrigated cotton crop without mulch (Control) as 1.20 and 0.50 , respectively. The corrected $\mathrm{K}_{\mathrm{c} \text { mid }}$ and $\mathrm{K}_{\text {cend }}$ for local conditions for 2013-14 and 2014-15 were 1.22 and 0.48 and 1.23 and 0.48 as per equation 3 and 4 respectively.

$\boldsymbol{K}_{c}$ for mulched cotton : FAO-56 suggested $\mathrm{K}_{\mathrm{c} \text {-ini }}, \mathrm{K}_{\mathrm{c} \text {-mid }}$ and $\mathrm{K}_{\mathrm{c} \text { - }}$ end values for cotton crop under plastic mulch $\left(\mathrm{M}_{1}\right.$ and $\left.\mathrm{M}_{2}\right)$ was $0.1,1.063$ and 0.45 respectively. These values were corrected
$0.1,1.036$ and 0.425 for local conditions as per the procedure suggested by FAO 56 using equation 3 and $4 . \mathrm{K}_{\mathrm{c}}$ values of cotton for $\mathrm{M}_{3}$ were estimated to be $0.1,1.25$ and 0.45 for $\mathrm{K}_{\mathrm{c} \text {-ini, }}$, $\mathrm{K}_{\mathrm{c} \text {-mid }}$ and $\mathrm{K}_{\mathrm{c} \text {-end, }}$ respectively and corrected values were 0.1 , 1.13 and 0.43 for $\mathrm{K}_{\mathrm{c} \text {-ini }}, \mathrm{K}_{\mathrm{c} \text {-mid }}$ and $\mathrm{K}_{\mathrm{c} \text {-end, }}$ respectively.

$K_{c}$ based on moisture sensor observations : Temporal variation of $\mathrm{ET}_{\mathrm{a}} / \mathrm{ET}_{\mathrm{o}}$ depicts the seasonal trend of sensor based $\mathrm{K}_{\mathrm{c}}$, whereas the spikes are due to high rates of evapotranspiration. Sensor based $\mathrm{K}_{\mathrm{c}}$ curves were compared with the adjusted FAO 
$\mathrm{K}_{\mathrm{c}}$ curves for different mulches and irrigation regimes. Adjusted $\mathrm{FAO} \mathrm{K}_{\mathrm{c}}$ remain same for a particular mulch at all irrigation regimes (Fig. 1).

The comparison of $\mathrm{K}_{\mathrm{c}}$ curves for $\mathrm{M}_{1}, \mathrm{M}_{2}, \mathrm{M}_{3}$ and $\mathrm{C}$ as per FAO $\mathrm{K}_{\mathrm{c}}$ and sensor based $\mathrm{K}_{\mathrm{c}}$ at $\mathrm{I}_{2}$ and $\mathrm{I}_{1}$ differed considerably during both years. Sensor based $\mathrm{K}_{\mathrm{c}}$ at mid stage deviated maximum compared to FAO adjusted $\mathrm{K}_{\mathrm{c}}$. Sensor based $\mathrm{K}_{\mathrm{c} \text {-mid }}$ at $\mathrm{M}_{1}, \mathrm{M}_{2}, \mathrm{M}_{3}$ and $\mathrm{C}$ observed $27.6 \mathrm{per}$ cent, 30.0 per cent, 27.4 per cent and 31.8 per cent lower than adjusted FAO $\mathrm{K}_{\mathrm{c}}$ at $\mathrm{I}_{1}$. Adjusted FAO $\mathrm{K}_{\mathrm{c}}$ overestimated $\mathrm{ET}_{\mathrm{c}}$ at all growth stages during two consecutive years.A sensor based $\mathrm{K}_{\mathrm{c}}$ curves not only differed considerably among the two years but were also different than adjusted FAO K ${ }_{c}$ values (Table 1). Significant difference was observed among different treatments under mulch and irrigation as well as in interaction also. $\mathrm{M}_{1}$ yielded lower $\mathrm{K}_{\mathrm{c}}$ values at all growth stages as compared to $\mathrm{M}_{3}$ and Control, whereas, $\mathrm{K}_{\mathrm{c} \text { - }}$ ini, $\mathrm{K}_{\mathrm{c} \text {-dev }}$ and $\mathrm{K}_{\mathrm{c} \text {-mid }}$ of $\mathrm{M}_{1}$ was at par with $\mathrm{M}_{2}$ at both irrigation regimes. Control treatments yielded 72.2 per cent and 66.9 per cent higher $\mathrm{K}_{\mathrm{c}}$ at initial stage as compared to $\mathrm{M}_{1}$ at $\mathrm{I}_{1}$ and $\mathrm{I}_{2}$ respectively (Fig. 2 and 3). Farahani et al., (2008) also reported that during the mid-season stage, the adjusted FAO $\mathrm{K}_{\mathrm{c}}$ was 24 per cent higher than the locally developed $\mathrm{K}_{\mathrm{c}}$.

Irrigation water demand was also estimated using Pan ET method using adjusted FAO $\mathrm{K}_{\mathrm{c}}$ for respective treatments and compared with water requirement estimated using sensor based ET values depicted in Table 2. It indicated that cumulative irrigation water estimated by Pan ET ${ }_{c}$ approach was higher of 16.1 per cent and 13.3 per cent than sensor based irrigation at $I_{1}$ and $I_{2}$ respectively (Prajapati and Subbaiah, 2018).

\section{CONCLUSIONS}

Crop coefficient curves for silver black plastic mulch, biodegradable plastic and wheat straw mulched cotton was developed for two irrigation regimes. Two sets of $\mathrm{K}_{c}$ curves were developed, the generalized $\mathrm{K}_{\mathrm{c}}$ values published by FAO that were adjusted for local climate, and the sensor based $\mathrm{K}_{\mathrm{c}}$ curves as the ratio of measured $\mathrm{ET}_{\mathrm{a}}$ to $\mathrm{ET}_{\mathrm{o}}$ for the two years. Sensor based $\mathrm{K}_{c}$ curves not only differed among the two years, but also from the adjusted FAO $\mathrm{K}_{\mathrm{c}}$ values. Silver black plastic mulch has smaller deviation in sensor based $\mathrm{K}_{\mathrm{c}}$ at different stages with biodegradable plastic mulch at $0.8 \mathrm{IW} / \mathrm{ET}_{\mathrm{c}}$ and $1.0 \mathrm{IW} / \mathrm{ET}_{\mathrm{c}}$. Much more deviation seen for sensors based $\mathrm{K}_{\mathrm{c}}$ between Silver black plastic mulch and Control at $1.0 \mathrm{IW} / \mathrm{ET}_{\mathrm{c}}$ and $0.8 \mathrm{IW} / \mathrm{ET}_{\mathrm{c}}$. Silver black plastic mulch observed 72.2, 29.0 and 66.9 and 14.8 per cent, lower over control for $\mathrm{K}_{\text {c ini }}, \mathrm{K}_{\mathrm{c} \text {-dev }}$ stage at $1.0 \mathrm{IW} / \mathrm{ET}$ 。 and $0.8 \mathrm{IW} / \mathrm{ET}_{\mathrm{c}}$ respectively. The use of the adjusted $\mathrm{FAO}$ $\mathrm{K}_{\mathrm{c}}$ values overestimated seasonal crop evapotranspiration thus cautioning against their blind application without some verification. The development of $\mathrm{K}_{\mathrm{c}}$ curves for $\mathrm{Bt}$. cotton was pursued because of its simplicity and limited data requirement for irrigation scheduling and water management.

\section{REFERENCES}

Allen, R.G., Pereira, L.S., Raes, D. and Smith, M. (1998). Crop evaporanspiration (guide lines for computing crop water requirements). FAO Irr. Drain. Paper No. 56.300 pp.

Chowdhary, A. and Shrivastava, R.K. (2010). Reference Crop Evapotranspiration estimation using Artificial Neural Networks. International. J. Eng. Sci. Technol., 2(9): 4205-4212.

Farahani, H. J., Oweis, T. Y. and Izzi, G. (2008). Crop coefficient fordrip-irrigated cottonin a Mediterranean environment. Irrig.Sci.,26 (5):375-383.

Hajare, H.V., Raman, N.S. and Jayant Dharkar, E.R.(2008). New technique for evaluation of crop water requirement. WSEAS Transactions on Environment and Development. 5(4): 436-446.

JaspinderKaur, Gill,K.K., SamanpreetKaur and Rajan Aggarwal (2017). Estimation of crop coefficient for rice and wheat crops at Ludhiana. J. Agrometeorol., 19(2): 170-171.

Mariani, L. and Ferrante, A. (2017). Agronomic management for enhancing plant tolerance to abiotic stresses-drought, salinity, hypoxia, and lodging.Horticulturae., 3(4):52.

Prajapati, G. V. and Subbaiah, R. (2018). Combined response of irrigation system regimes and mulching on productivity of Bt.Cotton.J.Agrometeorol., 20(Special issue-"NASA" Part-II):47-51

Rahimikhoob,A., Behbahani, M.R. and Fakheri, J. (2012). An evaluation of four reference evapotranspiration models in a subtropical climate. Water Resour. Manag., 26 (10):2867-2881.

Rajendran, K., Mohamed Amanullah, M. and Vaiyapuri, K. (2012). Effect of drip irrigation on Bt. Cotton yield. Madras Agric. J., 99(1-3):77-78. 